\title{
Shared Value Literature Review: Implications for Future Research from Stakeholder and Social Perspective
}

\author{
Asoke Rocky Mehera ${ }^{1}$ \\ ${ }^{1}$ School of Management \& Enterprise, University of Southern Queensland, Brisbane, Australia \\ Correspondence: Asoke Rocky Mehera, School of Management \& Enterprise, University of Southern \\ Queensland, Brisbane, Australia. E-mail: australiarocky@gmail.com
}

Received: October 9, 2017 Accepted: October 30, $2017 \quad$ Online Published: November 2, 2017

doi:10.5539/jms.v7n4p98 URL: http://doi.org/10.5539/jms.v7n4p98

\begin{abstract}
The review of the literature on shared value has denoted that this concept been approached as both generic and theoretical/conceptual framework for the simultaneous creation of social and economic value. Based upon the dominant trends in shared value literature, the proposed study has attempted to provide two broad strategic directions (i.e., stakeholder engagement, social innovation) regarding further research around shared value creation. The significance of the study has been demonstrated in the fact that these two new directions on stakeholders and society would expand the three-level framework of shared value toward a multi-level holistic framework for co-creation of value.
\end{abstract}

Keywords: creating shared value (CSV), stakeholder engagement and social innovation

\section{Introduction}

\subsection{Introduction to the Problem}

By the turn of the century, the capacity of a corporation to respond to social pressure by educated customers (involved in innovative interaction and unique product development as collaborators and developers) were considered important from the perspective of value co-creation (Prahalad \& Ramaswamy, 2004). During the early years of the twenty-first centuries, a long-term sustainable approach for inclusive growth has facilitated the emergence of various business theories and models, namely firm-value maximization (Jensen, 2002), sustainable value (Hart \& Milstein, 2003), blended value (Emerson, 2005), conscious capitalism (Sisodia, 2007), inclusive model (UNDP, 2008), social business (Yunus, 2008), and sustainable value (Laszlo, 2008). Following the global financial crisis (2008-2009), shared value framework (Porter \& Kramer, 2011) has proposed a three-level business model (i.e., re-conceiving products/markets, reconfiguring value chain, and clustered collaboration) with a broader value proposition for gaining a competitive advantage while co-creating social and economic output. The problem lied in the determination of current trends in shared value literature to denote future implications on CSV research mechanism from stakeholder engagement and social innovation perspective.

\subsection{Exploring Importance of the Problem}

The importance of exploring current shared value literature lied in understanding whether shared value concept is utilized as a generic or strategic notion as far as value creation is concerned. The importance of the problem of shared value (literature) trend determination is based on two dominant constructs (stakeholder engagement and social innovation). In the post-GFC competitive era, it became important to create economic value in a way that also "created value for society by addressing its needs and challenges" (Porter \& Kramer, 2011, p. 64).

\subsection{Definition of Valuable Constructs}

- Value Creation: "The actual value is created by a firm through transforming resources (i.e., capital, labour, and raw material) into products and services, which satisfy customer needs" (Besanko et al., 2010, p. 372).

- Co-creation of Value: The co-creation has been defined as "the joint creation of value by the company and the customer; allowing the customer to co-construct the service experience to suit their context" (Prahalad \& Ramaswamy, 2004, p. 8).

- $\quad$ Creating Shared Value (CSV): Shared value is a business model encompassing "policies and operating practices that enhance the competitiveness of a company while simultaneously advancing the economic and social conditions in the communities in which it operates" (Porter \& Kramer, 2011, p. 66). 
- Value Chain: The value chain is the "process or set of activities in the production system for diagnosing and enhancing competitive advantage and representing opportunities for reducing costs and developing product differentiation strategies" (Burke, 1999, p. 34).

- Value Proposition: Lanning \& Michaels (1988) have defined value proposition as "a clear, simple statement of the benefits, both tangible and intangible, that the company will provide, along with the approximate price it will charge each customer segment for those benefits" (p. 2).

- Product Innovation (i.e., Re-conceiving Products): Product innovation is the creation and subsequent introduction of a good or service that is either new, or an improved version (with enhanced functionalities) of previous goods or services (Developed by Researcher, 2017).

- Shareholder and Stakeholder Value: Shareholder value creation is a "means of maximising long-term free cash flow, which provides the appropriate approach to judging alternative strategies and subsequent performance (Mauboussin, 2011, p. 1). Stakeholder value maximisation has been defined as "organised efforts in focusing on the interests of other stakeholders to increase their willingness to support a firm's operation for value creation" (Deng et al., p. 83).

- Clustered Collaboration: The United Nations (United Nations, 2017) has defined clustered collaboration as "various inclusive local partnerships built upon principles and values, a shared vision, and shared goals that place people and the planet at the centre" (p. 1).

- Social Innovation: World Economic Forum (2016) has defined social innovation as a "strategic and collaborative mechanism to turn societal challenges into opportunities (by setting up Sustainable Development Goals) that enhance business growth and long-term sustainable competitiveness" (p. 2).

- Community Resilience: Resilient community is "a collaborative community, which identifies their problems, and strives together for solution, with a follow-up action for a sustained post-disaster resilience strategy at the social or community level" (Orbits et al., 2010, p. 283).

- Financial Inclusion: The World Bank (2017) has defined financial inclusion as "individual and business access to useful and affordable financial products and services that meet their needs-transactions, payments, savings, credit and insurance - delivered in a responsible and sustainable way" (p. 1).

- Co-innovation of Value: Lee et al. (2012) have defined co-innovation "as a new innovation paradigm, where new ideas and approaches from various internal and external sources are integrated in a platform to generate new organizational and shared values" (p. 817).

\subsection{Creating Shared Value Business Model}

The three levels of shared value are as follows (Porter \& Kramer, 2011): 1) re-conceiving products and markets (changing value propositions to meet societal needs through products and services addressing unserved or underserved customers in the market); 2) re-defining the value-chain (re-configuration of operational practices and productivity based on input access, resource utilization, innovation and efficiency); and 3) enabling local cluster development (supporting industries and logistical infrastructure around, and interconnected community as a source of productivity). [Refer Appendix A]

The "Creating Shared Value" (i.e., CSV) business model can generate simultaneous business results (improvements in productivity, market expansion, supply chain, collaborative innovation, and profitability) and social results (improvements in social innovation, community resilience, regional development, infrastructure and skilling of host communities) (Porter et al., 2012). Bockstette \& Stamp (2011) have opined that shared value creation (investments in long-term business competitiveness that simultaneously address social and environmental objectives) is strategically positioned within the interactive arena of social value creation (investments that address social and environmental objectives) and business value creation (investments in long-term competitiveness). For long-term maximization of value, Porter \& Kramer (2011) have identified two factors as follows: "sustainable innovation in operations" and "identifying points of intersection between the company and society" (p. 91).

To be able to integrate shared value in the company's business model, both organizations and society must recognize the dependence on the inside-out linkages (every activity in a company's value chain affects society) and outside-in linkages (external social conditions influencing corporations' productivity and competitiveness). There are two key areas essential for successful shared value organizations are as follows: 1) "materiality" (Hills et al., 2012) leading to business strategy for financial performance and 2) "intentionality" (Gradl \& Jenkins, 2011) leading to resource innovation within a cluster. Previously, Porter \& Kramer (2011, p. 72) have argued that "productivity, competitiveness, and innovation rely crucially on regional clusters of suppliers/businesses and a 
logistical infrastructure upon" (p. 72).

Building on the Porter \& Kramer's (2011) CSV business model, Pfitzer et al. (2013) have proposed a five-step framework of shared value strategy as follows: 1) identifying and embedding-embedding a social purpose (identifying current global business threats and opportunities) and prioritise social issues to periodically increase revenue or reduce costs; 2) defining - rigorously defining the social need with a comprehensive view of the social problem - making the business case stronger by modeling the potential business and social results relative to the costs, 3) execution-creating the optimal innovation structure (organizational structure encourages innovation and costly experimentation with clustered collaboration and NGO/government support), 4) measuring - measuring the social and business value (measure actually realized profits related to social progress), 5) co-creation-simultaneous sharing with external stakeholders and shareholders.

Shared Value measurement metrics include impact assessment to evaluate strategic effectiveness, and comparison of sustainability/social innovation metrics (of product/process) with resource utilization for cost savings, nutrition index and assessment of local supply chain network. The integrated shared value strategy and measurement process is represented in four steps as follows (Porter et al., 2012): 1) identify, prioritise, embedding and defining the social issues to target, 2) make the business case by creating optimal innovation structure and modeling the potential business and social results, 3) track progress regarding social and business value by assessing inputs (of corporate resources) and socio-economic performance, and 4) creating with external stakeholders (further refine shared value strategy following an assessment of social and business returns).

\section{Relevant Scholarships: Present Trends and Future Implications}

Since the shared value framework was propounded recently by Harvard academics (Porter \& Kramer, 2011); the scholarship, to a certain extent, is limited to North American, Scandinavian, and German literature (i.e., shared value creation) of the present decade. This predominance of shared value literature is proven by the fact that North American and Scandinavian corporations are in the forefront of the simultaneous creation of economic and social value

\subsection{Literature Review: Shared Value}

To supersede corporate social responsibility in guiding community investment, shared value commercial business model (Porter \& Kramer, 2011) has helped to identify the most material issues (i.e., skills deficiency, health issues, resource inefficiency, value chain incompetency) with new value proposition and innovation in production, processes, resource utilisation, technical collaboration, and value chain composition for opening new markets. Later, Hill et al. (2012) have emphasised on the points of leverage to redefine corporate business strategies for emerging markets; whereas Porter et al. (2012) have emphasised on re-imagining products, value chains, and collaborations within the corporate ecosystem. The recent strategic management literature has linked corporate economic and social values as follows: value for shareholders and stakeholders (Verboven, 2011), social and financial value creation (Pirson, 2012), social benefit alongwith business value (Pfitzer et al., 2013), and societal values based on financial position (Seele \& Lock, 2014). The shared value concept is "to recognize that societal needs, not just conventional economic needs while defining markets" (Bosch-Badia et al., 2013, p. 12).

Scholars have approached shared value creation from various perspectives combining various aspects of corporate social responsibility, sustainability, and shared value creation. Junge (2011) has argued that social responsibility of corporations has led to the competitive advantage in a market; whereas Maltz \& Schein (2012) have explained that there are significant opportunities for optimisation of shared value through a combination of support mechanisms (i.e., supply chain expertise, collaborative capacity, R \& D capabilities). Moscardo (2013) has emphasised on value creation through a supply chain, where the processing (of raw materials), production and movement of goods and services are important. In line with this supply chain trend, Biggemann et al. (2014) have advocated for the importance of value chain in following terms: "The value chain focuses on identifying consumer's wants and needs and then rallying resources to create a product or service that meets these needs" ( $p$. $305)$.

Organizations can become “co-creators of social and economic value' (Porter et al., 2012, p. 17) through cross-sector partnerships based on differentiation (new market opportunities through leveraging social needs). From a sustainable competitive advantage perspective, shared value has integrated entrepreneurial and infrastructural innovation for co-creation of value (Gyrd-Jones \& Kornum, 2013). Through an article in Harvard Business Review, titled "Innovating for Shared Value", Pfitzer et al. (2013) have emphasized on stakeholders to be involved in the treatment of problems (Pfitzer et al., 2013), as organizations need to cater the interests of a 
broad range of stakeholders for value creation (Harrison \& Wicks, 2013). Following this trend, Kindemann (2013) has affirmed that innovation has relied crucially on regional clusters of related businesses and logistical infrastructure; and a successful business needs a well-functioning community, which creates demand for its services or products. Scholz \& De los Reyes (2015) have summarized the attractiveness of shared value framework in terms as follows: "CSV provides a mantra of fundamental compatibility of societal and entrepreneurial interest" (p. 195). As far as consumer-centric and community infrastructure-oriented approach of corporations are concerned, Scholz \& De los Reyes (2015) and Breidbach \& Maglio (2016) have emphasized on the fact that shared value has promoted the societal and entrepreneurial strategies for better corporate performance leading to the benefit of the society. To achieve social legitimacy of capitalism, business is needed to "create shared value innovation and productivity" (Rendtorff, 2017, p. 129).

The shared value terminology has been interpreted differently by the academics. The analysis of practical instances of shared value has illustrated how shared value indeed remains a "sweet spot" between social and organizational benefit (Dembek et al., 2016, p. 235). Shared Value (CSV) is mainly conceived as "a win-win perspective that offers a solution to these legitimacy issues, which entails greater collaboration and more proactive approaches to stakeholder management" (Voltan et al., 2017; p. 354). As far as a business case for CSV is concerned, Molthan-Hill (2015) has advocated that German managers' are focusing on the firm's (ultimate) survival as criteria for economic rationale, rather than the British-American focus on increasing profitability. Ahen \& Zettinig (2015) have argued for "sustainable value co-creation through innovative ability and cooperative investments...... among the firm, consumers, business and non-business players" (p. 94). CSV is a "distinct, powerful, and transformational model that is embedded in the core purpose of the corporation" (Porter \& Kramer, 2014, p. 149) that has promoted executives to think strategically for competitive advantage. Organisations have generated collaborative advantage (Glasbergen, 2010) by gaining and sharing information, knowledge, and skills. Actually, sustainable competitive advantage is gained "by catering to the interests of consumers, employees, and the natural environment; and hence, firms are able to secure intangible assets such as legitimacy, reputation, and trust" (Flammer \& Kacperczyk, 2015, p. 1984).

In the recent literature, the concept of shared value is debated as a generic notion with a prominent buzzword and theoretical framework. A review by Dembek et al. (2016) have divided all the definitions into two groups as follows: 1) 13 out of 30 articles have used the shared value definition by Porter \& Kramer (2011) as a theoretical concept, and 2) 17 out of 30 articles have depicted shared value in terms of a generic common word from stakeholder perspective. Shared value articles can be categorized into two broad categories as follows: (1) means to create shared value, and (2) resulting outcomes of shared value. A tabular representation of categorized shared value articles has been provided below.

Table 1. Categorization of views within shared value literature

\begin{tabular}{ll}
\hline $\begin{array}{l}\text { Categorisation of Shared } \\
\text { Value Articles }\end{array}$ & Shared Value Aspects Emphasised in Literature \\
\hline Means to Create Shared & global commercial initiatives (Maltz \& Schein, 2012); and determinants of corporate abilities (Brown \& \\
Value & Knudsen, 2012; Carter \& Greer, 2013; and Schmitt \& Renken, 2012) \\
Resulting Outcomes of & $\begin{array}{l}\text { economic value (Brown \& Knudsen, 2012); social and environmental value (Dubois \& Dubois, 2012; } \\
\text { Shared Value }\end{array}$ \\
& $\begin{array}{l}\text { Srivastava \& Kennelly, 2013); social and financial value (Pirson, 2012); value chain and society (Wearne } \\
\text { et al., 2012); economic and social benefit (Porter \& Kramer, 2006/2011); public-private ties for strategic } \\
\text { value creation (Kivleniece \& Quelin, 2012); firm-value and stakeholders (Maltz et al., 2011); stakeholder } \\
\text { needs, and resources to upgrade quality of life (Korhonen, 2013) }\end{array}$ \\
\hline
\end{tabular}

Source: Developed by the researcher.

The triple bottom line "does not provide a basis for considering the relative value of business decisions to the firm, the environment, and society" (Maltz et al. 2011, p. 345). As no universal approach to measuring shared value currently exists, Pfitzer et al. (2013) have proposed a three-step assessment: (1) estimate business and social value linking change in social condition to profit; (2) establish intermediate measures and track progress to validate (or invalidate) the anticipated link; (3) assess the shared value produced by measuring the ultimate social and business benefits. While deploying indicators to measure shared value, Spritzes \& Chapman (2012) have used socio-economic efficiency analysis consisting of an evaluation of triple bottom line indicators alongwith the life cycle of a specific product. Spritzes et al. (2013) have emphasized on measurement tools through both organizational indicators (financial value encompassing profitability, growth, competitive capabilities, and strategic repositioning; and intangible value encompassing reputation, risk reduction, access to 
government, and long-term legacy) and social indicators (positive impact, reduced negative impacts etc.).

The shared value in literature in the present decade was represented from broadly five viewpoints as follows: 1) resource-based view, 2) social innovation and entrepreneurship, 3) mutual value, 4) triple bottom line, and 5) stakeholder view. The resource-based view has emphasized on cost-benefit analysis (Maltz et al., 2011); whereas a conscious capitalist approach has promoted social innovation and entrepreneurship (Driver, 2012; Crane et al., 2014). Based on dominant triple bottom line ideology (Elkington, 1997); the creation of simultaneous socio-economic-environmental value has been proposed (Shrivastava \& Kennelly, 2013). Although the concept of mutual value has been proposed from customer (bottom of the pyramid) perspective; but, it has actually strengthened the tenets of the stakeholder theory (Strand \& Freeman, 2015).

Table 2. Major trends in shared value literature

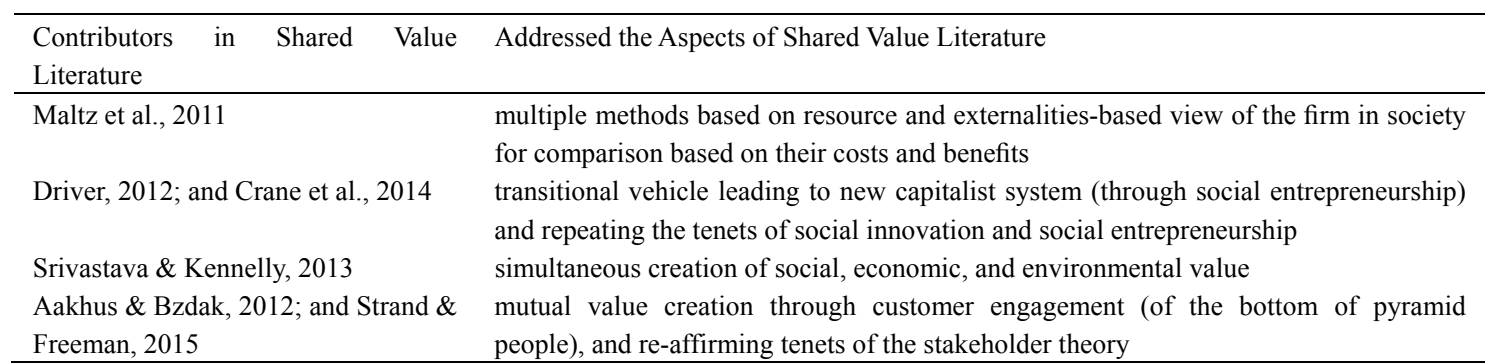

Source: Developed for the research.

\subsection{Evaluation of Shared Value Literature}

Shared value concept is much debated in the present decade either as a "sweet spot" between corporate economic and societal values (Porter \& Kramer, 2011; Moon et al., 2011; Bosch-Badia et al., 2013; Pfitzer et al., 2013), or as a blind spot with conflicting social and economic interests (Aakhus \& Bzbak, 2012; Brown \& Knudsen, 2012; Crane et al., 2014). Porter \& Kramer (2011) have argued that CSV concept is not built upon a passive logic of "what is good for business is good for society" (Aakhus \& Bzbak, 2012, p. 237); rather it is a pro-active multi-level approach for value creation based on core business strategy. Also, Porter \& Kramer (2011) have already acknowledged the fact that "not all social problems can be solved through shared value solutions" (p. 77). On the contrary, Aakhus \& Bzdak (2012) have criticized shared value for reducing the friction between business and society; but still unable to provide a framework for addressing sustainability and development from a holistic perspective. Following this trend, Crane et al. (2014) have argued that the concept has simplified the complexity of social and environmental issues, meaning that companies may be driven "to invest more in easy problems and decoupled communication strategies than in solving broader societal problems" (Crane et al., 2014, p. 137).

The shared value business model has been criticized by academics (Beschorner, 2013; Crane et al., 2014) for adopting non-unique proposition and narrow reductionist approach (as some social ills do not offer economic opportunities), while over-emphasizing on economic logic (benefits relative to costs). While discussing about social inclusion in market mechanism (through applied knowledge), Leandro \& Neffa (2012), have prioritized social technology (i.e., application of knowledge, innovation, and local potential) over shared value in terms as follows: "Social technology is much more autonomous and generates more social value than shared value, because it develops a network of people connected with economic and social development, resulting in a decrease in inequality" (p. 488). In this context, it is noteworthy that while adjusting capitalism (through rethinking capitalism process), shared value has basically argued for "economic rationality as the sole tool for smart management, with a faith in innovation and growth" (Beschroner, 2013, p. 111). From a radical and systemic perspective, Beschorner \& Hajduk (2017) have criticized shared value as follows: "Shared value fails to grab society's expectations and challenges, because social contexts cannot be understood by exclusively relying on categories of utility" (p. 33). Recently, Rendtorff (2017) has attracted our attention toward theoretical simplification (of profit maximisation) by Friedman (1970) and Porter \& Kramer (2011), while advocating for an organisational role in society based on a holistic understanding of business ethics. Crane et al. (2014) have described the core tenets of shared value as already being applied by "Benefit Corporation" (2010) in the US and by hybrid organisation "Grameen Bank" (1983) in Bangladesh. Crane et al. (2014) have also emphasized on the resemblance of "Creating Shared Value" (Porter \& Kramer, 2011) and "Stakeholder Theory" (Freeman, 1984) [stakeholders value enhances shareholder value] and "Blended Value" concept (Emerson, 2003) [simultaneous 
perusal of profit and socio-environmental targets]. Recently "conscious capitalism" (higher purpose and core values, conscious leadership, conscious culture and management, and stakeholder integration) [Mackey \& Sisodia, 2013] ideology has strengthened the concept of shared value. Although shared value is accused of ignoring the capitalist tensions inherent to commercial business activities (Crane et al., 2014), it could be a practical conscious capitalist approach for elevating social goals to a strategic level in the business process.

Shared value has been criticized from stakeholder perspective as Porter \& Kramer (2011) have not provided any guidance on how to manage trade-offs while disregarding other societal stakeholders (Beschorner, 2013). The societal perspective on value creation must include multi-stakeholder intense dialogue processes (leading to potential tensions) to ensure broader solutions on the problems (Crane et al., 2014; Schultz et al., 2013). To judge, whether the so-called shared value sweet spots are free from tensions and conflicts; various scholars (Dembek et al., 2016; Christensen \& Cheney, 2011; Schultz et al., 2013) have suggested multiple stakeholder perspectives to gain a more insightful understanding. The instrumental approach (alongwith corporate-centric perspective) has been challenged by the political-normative approach, which prompted organisations to go beyond narrow profit-seeking and to emphasise on solving societal issues through dialogue with societal stakeholders (Seele \& Lock, 2014; Lock et al., 2016).

\subsection{Implications for Further Research on Value Creation}

The future research on shared value should be based on the clarification of the strategic concept of shared value though means, outcomes, and beneficiaries while nourishing social capital and synonymous concepts (CSR, sustainability, blended value, conscious capitalism) from a stakeholder perspective. It is essential to re-consider implications of analyzing shared value at a project or initiative level [example-Dow Chemical's Nexera canola and sunflower seeds project] as proper value creation has demanded a holistic mechanism and properly addressing of sweet-spot tensions (example-Nazava water filters). To fulfill this requirement, the study has emphasised on two components (i.e., stakeholder engagement, and social innovation), which were strongly advocated by United Nations (Sustainable Development Goals) and World Bank (Support for Innovation and Entrepreneurship).

The recent shared value literature review (Dembek et al., 2016) have depicted that approximately three-fifth of the academic contributors have defined shared value as a generic common word from stakeholder perspective, rather than a theoretical concept or conceptual framework as proposed by its proponents, namely Michael Porter and Mark Kramer of Harvard Business School. However, the emerging trends (i.e., stakeholder engagement and social innovation) during the post-GFC period have depicted that the shared value literature deviating toward the stakeholders and socio-communal perspective.

\subsubsection{Implications for Further Research on Value Creation from the Perspective of Stakeholder Engagement}

The concept of stakeholder management has been approached from various value-creation strategic mechanisms as follows: alignment of strategic goals and stakeholder requirements (Wolfe \& Putler, 2002), dynamic relationships between customers, suppliers, and investors (Post et al., 2002), organizational adaptation, and innovative collaboration (Rodriguez et al., 2002; Wheeler et al., 2003), creative solutions to complex issues (Svendsen \& Laberge, 2005), innovative strategies to outperform firm competitors (Harting et al., 2006), both stakeholders and social issues (Dentchev, 2009), instrumental stakeholder management and financial performance (Egels-Zandénand \& Sandberg 2010), and increase demand and innovation (Harrison et al., 2010). Later, stakeholder management has acquired a strategic dimension and stakeholder engagement was proposed for competitive advantage (Neil, 2009; Freeman, 2010; Wu, 2010), which eventually laid foundations for co-creation of value for treatment of problems (Pfitzer et al., 2013). The empirical finding of Wu's (2010) Ph.D. thesis (The Search for Sustainable Competitive Advantage: A Stakeholder Management Perspective) has suggested that "innovative activities require both entrepreneurship and strategies for managing multiple stakeholders" (p. 309). All stakeholders, acting in collaborative partnership, must be endeavoring to balance the three dimensions of sustainable development (i.e., economic, social and environmental) [Shrivastava \& Kennelly, 2013] for sustained progress without disrupting ecosystem (Dubois \& Dubois, 2012). Bulgacov et al. (2015) in their article titled "Differences in sustainability practices and stakeholder involvement" have represented a framework of analysis for strategic organizational sustainability while involving stakeholders.

Global investors and buyers have gradually realised the contextual embeddedness of stakeholders (and fulfilling their needs) in the supply chain (Pedersen et al., 2013; Soundararajan \& Brown, 2016). Tantalo \& Priem (2016) have emphasized on the integrative and collaborative principles of CSV as a way for managers to "entrepreneurially create new value for two or more essential stakeholder groups simultaneously, thereby increasing the size of the utility pie for those system members" (p. 315). Perrini et al. (2011) have attributed 
innovative approaches of value creation processes beyond solely serving managerial and shareholder interests.

Stakeholder theory has been presented as an original logic of CSV (Strand \& Freeman, 2015). The firm-centric instrumental concepts have promoted stakeholder needs assessment and stakeholder engagement for legitimacy building (Munro, 2013; Scherer et al., 2013; Castello et al., 2015). Voltan et al. (2017) found that CSV is often referenced in a generic sense "acknowledging the decreasing legitimacy of corporations and advocating for theoretical advancements in CSR and stakeholder engagement" (p. 352). Based on the integrative approach to business and society, Raimi et al. (2015) have opined for the "theoretical possibility of a CSR-entrepreneurship synergy" (p. 57) such as blended value (Emerson, 2003) and hybrid entrepreneurship (Battilana \& Lee, 2014). Banerjee \& Jackson (2017) have referred to CSV as part of "market-based measures at the base of the pyramid for alleviating poverty enhance social welfare" (p. 64). Actually, organisations are increasingly creating cross-sector collaborations (Dentoni et al., 2016) for an infrastructure for "inclusive growth" (George et al., 2012); not only corporate returns on invested capital (McGahan, 2012).

The holistic thematic component of stakeholder engagement is the most dominant literary trend for value creation, and it actually encompassed the component of customer engagement. A tabular representation of literature review of social innovation in the present decade was provided below.

Table 3. Current trend of value creation through stakeholder engagement

\begin{tabular}{|c|c|}
\hline $\begin{array}{l}\text { Dominant Current Trend for Future } \\
\text { Research on Value Creation }\end{array}$ & Current Value Creation Literature in the Stakeholder Engagement Domain \\
\hline Stakeholder Engagement & $\begin{array}{l}\text { innovative entrepreneurship and strategies for managing multiple stakeholders (Wu, 2010), value for } \\
\text { shareholders and stakeholders (Verboven, 2011), multiple methods based on resource and } \\
\text { externalities-based view of the firm in society for comparison based on their costs and benefits (Maltz et } \\
\text { al., 2011), leveraging the connections between social and economic progress (Maltz \& Schein, 2012), } \\
\text { socio-environmental sustainability affecting entire value chain and stakeholders) (Leandro \& Neffa, 2012), } \\
\text { collective strategy formulation through imagining a new value chain (Gouillart \& Billings, 2013), cater the } \\
\text { interests of a broad range of stakeholders (Harrison \& Wicks, 2013), understanding social needs to } \\
\text { co-create with external social stakeholders (Pfitzer et al., 2013), manage trade-offs, disregarding other } \\
\text { societal stakeholders (Beschorner, 2013), solving societal issues through dialogue with societal } \\
\text { stakeholders (Seele \& Lock, 2014; Lock et al., 2016)., value for stakeholders -focusing on the firm's areas } \\
\text { of technical expertise (Chandler, 2014), communicative and adaptive approach from stakeholder } \\
\text { perspective (Athanasopoulou \& Selsky, 2015; Hovring, 2017), and power-centric discourse analysis of } \\
\text { stakeholders (Hovring, 2017) }\end{array}$ \\
\hline
\end{tabular}

Source: Developed by the researcher.

\subsubsection{Implications for Further Research on Value Creation from the Perspective of Social Innovation}

Innovation in business has broadly denoted innovation in product/service offering, business model improvement, and/or operational efficiency that affects a large number of stakeholders'. Harvard Professor, Moss Kanter (1999) has articulated the notion of "social innovation" as a process for addressing community needs to develop business ideas for catering new markets and solving long-standing problems. Actually, social innovation is based on the ability to enhance community preparedness while building social capital, which provides opportunities for low-income individuals and communities to access the essential resources to fortify themselves through coping and adaptive mechanisms. The concept of co-creation (Prahalad \& Ramaswamy, 2004) [customers constructing the service experience] has led to co-innovation platform (Lee et al., 2012), which facilitated an organization to create value through five value creating avenues (i.e., new products/services/ventures, new customer value, new customer base, new efficiency of value chain, and new business model), based on "convergence, collaboration, and co-creation with partners (suppliers, partner organizations, outside collaborators, customers, and the general public at large)" (pp. 826-827).

Organisational and management innovation generally drove product and/or process innovation. Social innovation is considered as a subset of disruptive innovation (Christensen's, 2006) based on sustainable and inclusive concerns adding value to a business, customers, environment, and society. Organization for Economic Co-operation and Development (OECD, 2010) has depicted that social innovation deals with improving the welfare of individuals and communities through employment, consumption or interactive participation. Viswanathan \& Sridharan (2011) have suggested new product development opportunities for multifunctional product design, and development of user-centric products aligned with local context; whereas Michelini (2012) has proposed a specific model of the product innovation process (based on a consumer-ethics driven approach). 
Social innovation is a strategic (with the business model) and collaborative (with external stakeholders) mechanism to turn societal challenges (unemployment, malnutrition, lack of healthcare and micro-financial services) into opportunities (by setting up Sustainable Development Goals) [WEF, 2016]. The World Economic Forum Report (2016, p. 1) has listed four business opportunities in pursuing social innovation: 1) building future markets, 2) strengthening supply chains, 3) skills development, and 4) leveraging finance to back up social enterprises. Actually, investments in infrastructure (i.e., transport, irrigation, energy and information and communication technology), awareness of community resilience, and planned urbanization have been considered as essential elements (United Nations, 2017). The World Bank (2017) has emphasized on individual and business access to useful and affordable financial products and services that meet their needs in a sustainable way. The World Bank has also identified financially excluded groups (i.e., women, rural poor, and other remote or hard-to-reach populations, as well as informal micro and small firms) as one of the important components of Sustainable Development Goals.

Social innovation had also a vital impact on shared value creation as it facilitated the process of "meeting society's need for build a profitable enterprise" (Pfitzer et al., 2013, p. 3). Social innovation is really a crucial thematic component, which has paved way for community resilience. In fact, socially innovative and collaborative communities have identified their problems, and strived together for a solution at the social or community level (Orbits et al., 2010). Actually, organisations can use their core business competencies to provide solutions to social and environmental problems (Witt \& Stahl, 2016). The firm-centric approach can be misleading as it has failed to consider the complexity of social problems and motive of instrumental CSV leaders generating new profit sources by identifying such socio-environmental issues aligned with organisational strategy and bottom line (Mazutis \& Slawinski, 2015). Dentoni et al. (2016) and Waddock, (2012) have highlighted that social problems promote organizations to anticipate, and address (through dynamic capabilities and resource utilisation) the concerns of a wide range of stakeholders. Galuppo et al. (2014) have opined that "building socially sustainable organisations means managing complex multi-stakeholder processes that bring to the forefront an essential, physiological and sometimes paradoxical or conflicting nature" (p. 686).

The valuable thematic component of community resilience is totally moulded and driven by "social innovation", rather than conventional disaster preparedness only. A tabular representation of literature review of social innovation in the present decade was provided below.

Table 4. Current trend of value creation through social innovation

Dominant Current Trend for Future Current Value Creation Literature in the Social Innovation Domain

Research on Value Creation

Social Innovation

capability development of community resources to face change (Margis, 2010), value chain and society
(Wearne et al., 2012), new capitalist system through social entrepreneurship) (Driver, 2012), meeting
society's need for build a profitable enterprise' (Pfitzer et al., 2013), social innovation and social
entrepreneurship for value creation (Crane et al., 2014), turning societal challenges (unemployment,
malnutrition, lack of healthcare and micro-financial services) into opportunities (by setting up Sustainable
Development Goals) into strategic (with the business model) and collaborative (with external
stakeholders) mechanism diverted toward planned urbanization and investments in infrastructure to
achieve sustainable development and empowered communities (United Nations, 2013), and leveraging
finance to back up social enterprises while developing supply chains and skills (World Economic Forum
Report, 2016)

Source: Developed by the researcher.

\section{Conclusion}

While evaluating the current trends in value creation literature (including value creation frameworks and business models), two components (i.e., stakeholder engagement, and social innovation) became dominant, while organisations were favouring the pragmatic shared value framework (Porter \& Kramer, 2011). In the post-GFC era, large organisations have approached points of leverage (Hills et al., 2012) from a different perspective (i.e., community resilience through social/financial inclusion, sustainable development through stakeholder engagement) to gain competitive advantage. On the contrary, the shared value has also been considered as more of a buzzword than a theoretical concept (Dembek et al., 2016, p. 232). Based on firm-centric stakeholder approach, the findings of Voltan et al. (2017) have suggested that "the status of CSV as a "win-win" and a transformative solution is going out of favour, especially in non-Western contexts" (p. 358).

The future direction of research on value creation would depend upon the fact how the shared value business 
model is able to integrate stakeholder engagement and social innovation (as emphasized by the World Bank and the United Nations) perspective to make significant changes within the fields of business ethics, organizational management, theories of firm and contract. Inspite of some resemblance with instrumental stakeholder theory (Donaldson \& Preston, 1995), and lack of uniqueness (Crane et al., 2014; Strand \& Freeman, 2015; Strand et al., 2015); shared value has matured as a theoretical/conceptual framework, proven through robust value enhancing case studies (IKEA, Yarra, Nestle etc.) worldwide. Based on the literary trends, it became essential to attract the attention of researchers toward growing importance of stakeholder engagement and social innovation; and both aspects could enrich shared value as a comprehensive framework for co-creation of value (Prahalad \& Ramaswamy, 2004). Future research could entail the development of a multi-level business model for CSV that include non-firm and non-institutional perspectives within both western and non-western contexts. Further distinctions of integrative versus instrumental approaches to shared value could also be developed, alongwith a closer examination of four major elements for co-creation are as follows: experience mindset, a context of interactions for collective intelligence, engagement platform, and network relationships (Ramaswamy \& Gouillart, 2010). This approach to co-construction might expand the research area of stakeholder engagement (Hovring, 2017), social innovation and entrepreneurship (Crane et al., 2014), as far as the simultaneous creation of social and economic value is concerned.

\section{Reference}

Aakhus, M., \& Bzdak, M. (2012). Revisiting the role of Shared Value in the Business-Society Relationship. Business and Professional Ethics Journal, 31(2), 231-246. https://doi.org/10.5840/bpej201231211

Ahen, F., \& Zettinig, P. (2015). Critical perspectives on strategic CSR: What is sustainable value co-creation orientation? Critical Perspectives on International Business, 11(1), 92-109. https://doi.org/10.1108/cpoib-03-2012-0022

Athanasopoulou, A., \& Selsky, J. W. (2012). The social context of corporate social responsibility: Enriching research with multiple perspectives and multiple levels. Business and Society, 1-43.

Banerjee, S. B., \& Jackson, L. (2017). Microfinance and the business of poverty reduction: Critical perspectives from rural Bangladesh. Human Relations, 70(1), 63-91. https://doi.org/10.1177/0018726716640865

Besanko, D., Drano, D., Shan Lay, M., \& Schaefer, S. (2010). Economics of Strategy (5th edition). Evanston: Wiley.

Beschorner, T. (2013). Creating shared value: the one trick pony approach. Business Ethics Journal Review, 1(17), 106-112. http://doi.org/10.12747/bejr2013.01.17

Beschorner, T., \& Hajduk, T. (2017). Creating Shared Value: A Fundamental Critique. Berlin: Springer.

Biggemann, S., Williams, M., \& Kroc, G. (2014). Building in Sustainability, Social Responsibility and Value Co-creation. Journal of Business \& Industrial Marketing, 29(4), 304-312. https://doi.org/10.1108/JBIM-08-2013-0161

Bockstette, V., Pfitzer, M., \& Smith, D. (2014). Banking on shared value: How banks profit by rethinking their purpose. Retrieved from http://sharedvalue.org/resources/banking-shared-value

Bosch-Badia, M. T., Joan Montllor-Serrats, J., \& Tarrazon, M. A. (2013). Corporate social responsibility: From Friedman to Porter and Kramer. Theoretical Economics Letters, 11-15. https://doi.org/10.4236/tel.2013.33A003

Breidbach, C. F., \& Maglio, P. P. (2016). Technology-enabled value co-creation: An empirical analysis of actors, resources, and practices. Industrial Marketing Management, 56(1), 73-85. https://doi.org/10.1016/j.indmarman.2016.03.011

Brown, D., \& Knudsen, J. S. (2012). No shortcuts: Achieving shared value means changing your business culture. http://dx.doi.org/10.2139/ssrn.2179926

Bulgacov, S., Ometto, M. P., \& May, M. R. (2015). Differences in sustainability practices and stakeholder involvement. Social Responsibility Journal, 11(1), 149-160. https://doi.org/10.1108/SRJ-02-2013-0023

Burke, E. M. (1999). Corporate Community Relations: The Principle of the Neighbor of Choice. Westport: Praeger.

Carter, S. M., \& Greer, C. R. (2013). Strategic leadership: Values, styles, and organizational performance. Journal of Leadership and Organizational Studies, 20(4), 375-393. https://doi.org/10.1016/j.indmarman.2016.03.011 
Castello, I., Etter, M., \&Nielsen, F. A. (2015). Strategies of legitimacy through social media: The networked strategy. Journal of Management Studies, 53(3), 402-432. https://doi.org/10.1111/joms.12145

Chatterjee, S. (2016). Articulating globalization: Exploring the bottom of the pyramid (BOP) terrain. Organization Studies, 37(5), 635-653. https://doi.org/10.1177/0170840615604505

Christensen, C. M., Baumann, H., Ruggles, R., \& Sadtler, T. M. (2006). Disruptive innovation for social change. Harvard Business Review, 84(12), 94-101.

Crane, A., Palazzo, G., Spence, L. J., \& Matten, D. (2014). Contesting the value of creating shared value. California Management Review, 56(2), 130-151. http://dx.doi.org/10.1016/j.aos.2012.03.003

Dembek, K., Singh, P., \& Bhakhoo, T. (2015). Literature Review of Shared Value: A Theoretical Concept or a Management Buzzword? Journal of Business Ethics, 18(2), 153-190.

Deng, X., Kang, J. K., \& Low, B. S. (2013). Corporate social responsibility and stakeholder value maximisation: Evidence from mergers. Journal of Financial Economics, 110(1), 87-109. http://dx.doi.org/10.2139/ssrn.2067416

Dentchev, N. A. (2009). To What Extent is Business and Society Literature Idealistic? Business and Society, 48(1), 10-38. https://doi.org/10.1177/0007650307299222

Dentoni, D., Bitzer, V., \& Pascucci, S. (2016). Cross-sector partnerships and the co-creation of dynamic capabilities for stakeholder orientation. Journal of Business Ethics, 135(1), 35-53. https://doi.org/10.1007/s10551-015-2728-8

Donaldson, T., \& Preston, L. E. (1995). The stakeholder theory of the corporation: Concepts, evidence, and implications. Academy of Management Review, 20(1), 65-91.

Driver, M. (2012). An interview with Michael Porter: Social entrepreneurship and the transformation of capitalism. Academy of Management Learning and Education, 11(3), 421-431. https://doi.org/10.5465/amle.2011.0002A

Dubois, C. L., \& Dubois, D. A. (2012). Expanding the vision of industrial-organizational psychology contributions to environmental sustainability. Industrial and Organizational Psychology, 5(4), 480-483. http://dx.doi.org/10.1111/j.1754-9434.2012.01482.x

Elkington, J. (1997). Cannibals with forks: The triple bottom line of 21st-century business. United Kingdom: Capstone.

European Commission. (2011). Social business initiative: Creating a favourable climate for social enterprises, key stakeholders in the social economy and innovation. Retrieved from http://ec.europa.eu/internal_market/social_business/docs/COM2011_682_en.pdf

Fearne, A., Martinez, M. G., \& Dent, B. (2012). Dimensions of Sustainable Value Chains: Implications for Value Chain Analysis. Supply Chain management: An International Journal, 17(6), 575-581. https://doi.org/10.1108/13598541211269193

Flammer, C., \& Kacperczyk, A. (2015). The impact of stakeholder orientation on innovation: Evidence from a natural experiment. Management Science, 62(7), 1982-2001. https://doi.org/10.1287/mnsc.2015.2229

Freeman, R. E. (2010). Strategic Management: A Stakeholder Approach. Cambridge: Cambridge University Press. https://doi.org/10.1017/CBO9781139192675

Furst, M. (2017). Just when You Thought It Couldn't Get Worse, You Hear: The Business of Business Is Business-Some Reflections on a Self-Fulfilling Prophecy and Alternative Perspectives on the Purpose of Companies. In J. Wieland (Ed.), Creating Shared Value-Concepts, Experience, Criticism (pp. 55-77). Berlin: Springer. https://doi.org/10.1007/978-3-319-48802-8_5

Galuppo, L., Gorli, M., Scaratti, G., \& Kaneklin, C. (2014). Building social sustainability: Multi-stakeholder processes and conflict management. Social Responsibility Journal, 10(4), 685-701. https://doi.org/10.1108/SRJ-10-2012-0134

George, G., McGahan, A. M., \& Prabhu, J. (2012). Innovation for inclusive growth: Towards a theoretical framework and a research agenda. Journal of Management Studies, 49, 661-683. https://doi.org/10.1111/j.1467-6486.2012.01048.x

Glasbergen, P. (2010). Global action networks: Agents for collective action. Global Environmental Change, 20, 130-141. https://doi.org/10.1016/j.gloenvcha.2009.09.002 
Gradl, C., \& Jenkins, B. (2011). Tackling barriers to scale: From inclusive business models to inclusive business ecosystems. Retrieved from $\mathrm{http} / / / \mathrm{www} . \mathrm{ifc} . \mathrm{org} / \mathrm{wps} / \mathrm{wcm} / \mathrm{connect} / \mathrm{topics}$ _ext_content/ifc_external_corporate_site/inclusive+business/res ources/publications/pub_004_scaling+up+inclusive+business+advancing + the+knowledge+and + action + age nda

Gyrd-Jones, R. I., \& Kornum, N. (2013). Managing the co-created brand: Value and cultural complementarity in online and offline multi-stakeholder ecosystems. Journal of Business Research, 66(9), 1484-1493. http://dx.doi.org/10.1016/j.jbusres.2012.02.045

Harrison, J. S., Bosse, D. A., \& Phillips, R. A. (2010). Managing for Stakeholders, Stakeholder Unity Functions, and Competitive Advantage. Strategic Management Journal, 31(1), 58-74. https://doi.org/10.1002/smj.801

Hart, S. L., \& Milstein, M. B. (2003). Creating Sustainable Value. Academic of Management Executive, 17(2), 56-69. https://doi.org/10.5465/AME.2003.10025194

Hills, G., Russell P., Borgonovi V., Doty, A., \& Iyer, L. (2012). Shared value in emerging markets: How multinational corporations are redefining business strategies to reach poor or vulnerable populations. Retrieved

from http://sharedvalue.org/resources/shared-value-emerging-markets-how-multinational-corporations-are-redefi ning-business

Hovring, C. M. (2017). Corporate social responsibility as shared value creation: toward a communicative approach. Corporate Communications: An International Journal, 22(2), 239-256. http://dx.doi.org/10.1108/CCIJ-11-2016-0078

Junge, N. (2011). The Contribution of Michael Porter and Mark Kramer's Concept of Creating Shared Value to CSR Theory. Nordersted: Grin Publication

Kanter, R. M. (1999). From spare change to real change: The social sector as beta site for business innovation. Harvard Business Review, 77(3), 122-128.

Kivleniece, I., \& Quelin, B. V. (2012). Creating and capturing value in public-private ties: A private actor's perspective. Academy of Management Review, 37(2), 272-299. https://doi.org/10.5465/amr.2011.0004

Korhonen, H. (2013). Organizational needs: A co-creation and human systems perspective. Journal of Business Market Management, 6(4), 214-227.

Lanning, M., \& Michaels, E. (1988). A Business is a Value Delivery System. Retrieved from http://www.dpvgroup.com/wp-content/uploads/2009/11/1988-A-Business-is-a-VDS-McK-Staff-Ppr.pdf

Lee, S. M., Olson, D. L., \& Trimi, S. (2012). Co-innovation: Convergenomics, collaboration, and co-creation for organizationalvalues. Management Decision, 50(5), 817-831. https://doi.org/10.1108/00251741211227528

Leonardo, L., \& Neffa, E. (2012). Is the integration of Shared Value Creation (SVC) with strategy management of productive organizations an innovative approach to environmental challenges faced by companies today? International Journal of Business Management, 3(2), 484-489.

Mackey, J., \& Sisodia, R. (2013). Conscious Capitalism: Liberating the Heroic Spirit of Business. Boston: Harvard Business Review Press.

Maltz, E., \& Schein, S. (2012). Cultivating Shared Value Initiatives: A Three Cs Approach. The Journal of Corporate Citizenship, 47(1), 55-74. https://doi.org/10.9774/GLEAF.4700.2012.au.00005

Maltz, W., Ringold, D. J., \& Thompson, F. (2011). Assessing and Optimising Corporate Social Initiatives: A Strategic View of Corporate Social Responsibility. Journal of Public Affairs, 11(4), 384-395. https://doi.org/10.1002/pa.384

Mauboussin, M. J. (2011). What shareholder value is really about. Harvard Business Review. Retrieved from https://hbr.org/2011/10/ceos-must-understand-what-crea

Mazutis, D. D., \& Slawinski, N. (2015). Reconnecting business and society: Perceptions of authenticity in corporate social responsibility. Journal of Business Ethics, 131(1), 137-150. https://doi.org/10.1007/s10551-014-2253-1

McGahan, A. M. (2012). Challenges of the informal economy for the field of management. Academy of Management Perspectives, 26(3), 12-21. https://doi.org/10.5465/amp.2012.0104

Michelini, L. (2012). Social Innovation and New Business Models: Creating Shared Value in Low-Income 
Markets. Berlin: Springer. https://doi.org/10.1007/978-3-642-32150-4

Molthan-Hill, P. (2015). Making the business case? Intercultural differences in framing economic rationality related to environmental issues. Critical Perspectives on International Business, 11(1), 72-91. https://doi.org/10.1108/cpoib-07-2012-0033

Moscardo, G., Lamberton, G., \& Wells, G. (2013). Sustainability in Australian Business: Principles and Practice. In G. Moscardo (Ed.), Sustainability, Economy and Society (pp. 1-34). Brisbane: Wiley.

Munro, V. (2013). Stakeholder preferences for particular Corporate Social Responsibility (CSR) activities and Social Initiatives (SIs): CSR initiatives to assist corporate strategy in emerging and frontier markets. The Journal of Corporate Citizenship, 51, 72-106. https://doi.org/10.9774/GLEAF.4700.2013.se.00007

Neil, J. (2009). Stakeholder Engagement: Road Map to Meaningful Engagement. Retrieved from http://www.fundacionseres.org/Lists/Informes/Attachments/700/Stakeholder\%20Engagement.pdf

O'Riordan, L., \& Fairbrass, J. (2014). Managing CSR stakeholder engagement: A new conceptual framework. Journal of Business Ethics, 125(1), 121-145. https://doi.org/10.1007/s10551-013-1913-x

Orbits, B. et al. (2010). Multi-layered Social Resilience. Progress in Development Studies, 10(4), 283-293. https://doi.org/10.1177/146499340901000402

Organization for Economic Co-operation and Developmen. (2010). SMEs, Entrepreneurship and Innovation. Retrieved from http://www.oecd.org/document/16/0,3746,en_2649_33956792_44938128_1_1_1_L00.html

Pedersen, E. R. G., Henriksen, M. H., Frier, C., Søby, J., \& Jennings, V. (2013). Stakeholder thinking in sustainability management: The case of Novozymes. Social Responsibility Journal, 9(4), 500-515. https://doi.org/10.1108/SRJ-08-2012-0101

Perrini, F., Russo, A., Tencati, A., \& Vurro, C. (2011). Deconstructing the relationship between corporate social and financial performance. Journal of Business Ethics, 102, 59-76. https://doi.org/10.1007/s10551-011-1194-1

Pfitzer, M., Bockstette, V., \& Stamp, M. (2013). Innovating for sharedvalue. Harvard Business Review, 91, 100-107.

Pirson, M. (2012). Social entrepreneurs as the paragons of shared value creation? A critical perspective. Social Enterprise Journal, 8(1), 31-48. https://doi.org/10.1108/17508611211226575

Porter, M. E., \& Kramer, M. R. (2011). The big idea: Creating shared value: Rethinking capitalism. Harvard Business Review. Retrieved from http://boost-afrique.weebly.com/uploads/2/5/0/7/2507823/hbr-creating_shared_value-developing_countriesabstract.pdf

Porter, M. E., \& Kramer, M. R. (2014). A response to Andrew Crane et al.'s article by Michael E. Porter and Mark R. Kramer. California Management Review, 56(2), 149-151.

Porter, M. E., Hills, G., Pfitzer, M., Patscheke, S., \& Hawkins, E. (2012). Measuring Shared Value: How to Unlock value by Linking Business and Social Results. Retrieved from http://www.hbs.edu/faculty/Publication\%20Files/Measuring_Shared_Value_57032487-9e5c-46a1-9bd8-90b d7f1f9cef.pdf

Prahalad, C. K., \& Ramaswamy, V. (2004). The Future of Competition. Boston: Harvard Business School Press.

Raimi, L., Akhuemonkhan, I., \& Ogunjirin, O. D. (2015). Corporate Social Responsibility and Entrepreneurship (CSRE): Antidotes to poverty, insecurity and underdevelopment in Nigeria. Social Responsibility Journal, 11(1), 56-81. https://doi.org/10.1108/SRJ-11-2012-0138

Ramaswamy, V., \& Gouillart, F. (2010). The Power of Co-creation. NY: Free Press.

Rendtorff, J. D. (2017). Creating Shared Value as Institutionalisation of Ethical Responsibilities of the Business Corporation as a Good Corporate Citizen in Society. In J. Wieland (Ed.), Creating Shared Value-Concepts, Experience, Criticism (pp. 119-139). Berlin: Springer. https://doi.org/10.1007/978-3-319-48802-8_7

Scherer, A. G., Palazzo, G., \& Seidl, D. (2013). Managing legitimacy in complex and heterogeneous environments: Sustainable development in a globalized world. Journal of Management Studies, 50(2), 259-284. https://doi.org/10.1111/joms.12014

Schmitt, J., \& Renken, U. (2012). How to earn money by doing good! Shared value in the apparel industry. Journal of Corporate Citizenship, 45(1), 79-103. https://doi.org/10.9774/GLEAF.4700.2012.sp.00007 
Scholz, M., \& De los Reyes, G. (2015). Creating Shared Value: Limits and Suggestions for Further Development. ZeitschriftfürWirtschafts- und Unternehmensethik, 16(2), 192-201.

Seele, P., \& Lock, I. (2014). Instrumental and/or deliberative? A typology of CSR communication tools. Journal of Business Ethics, 131(2), 401-414. https://doi.org/10.1007/s10551-014-2282-9

Shared Value Project Australia. (2015). The state of shared value in Australia [Report]. Retrieved from http://sharedvalue.org.au/wp-content/uploads/2015/08/2015-State-of-Shared-Value-in-Australia-Report-Do uble-Spread.pdf

Soundararajan, V., \& Brown, J. A. (2016). Voluntary governance mechanisms in global supply chains: Beyond CSR to a stakeholder utility perspective. Journal of Business Ethics, 134(1), 83-102. https://doi.org/10.1007/s10551-014-2418-y

Spritzes, H., \& Chapman, S. (2012). Creating shared value as a differentiation strategy-the example of BASF in Brazil. Corporate Governance, 12(4), 499-513. https://doi.org/10.1108/14720701211267838

Spritzes, H., Boechat, C., \& Franc,aLeao, S. (2013). Sustainability as a driver for innovation: Towards a model of corporate social entrepreneurship at Odebrecht in Brazil. Corporate Governance, 13(5), 613-625. https://doi.org/10.1108/CG-06-2013-0080

Strand, R., \& Freeman, R. E. (2015). Scandinavian cooperative advantage: The theory and practice of stakeholder engagement in Scandinavia. Journal of Business Ethics, 127(1), 65-85. https://doi.org/10.1007/s10551-013-1792-1

Strand, R., Freeman, R. E., \& Hockerts, K. (2015). Corporate social responsibility and sustainability in Scandinavia: An overview. Journal of Business Ethics, 127(1), 1-15. https://doi.org/10.1007/s10551-014-2224-6

Tantalo, C., \& Priem, R. L. (2016). Value creation through stakeholder synergy. Strategic Management Journal, 37, 314-329. https://doi.org/10.1002/smj.2337

The World Bank. (2017). Financial Inclusion. Retrieved from http://www.worldbank.org/en/topic/financialinclusion/overview

United Nations. (2013). Building Resilience and Social Cohesion by Leveraging Cultural Capital and Community Empowerment. Retrieved from https://www.cepal.org/sites/default/files/events/files/rio_03.2013_portofspain.building_resilience_social_co hesion_leveraging.eng_.pdf

United Nations. (2016). Revitalise the Global Partnership for Sustainable Development. Retrieved from http://www.un.org/sustainabledevelopment/globalpartnerships/

Verboven, H. (2011). Communicating CSR and business identity in the chemical industry through mission slogans. Business Communication Quarterly, 74(4), 415-431. https://doi.org/10.1177/1080569911424485

Viswanathan, M., \& Sridharan, S. (2011). Product Development for the BoP: Insights on Concept and Prototype Development from University-Based Student Projects in India. Journal of Product Innovation Management, 29(1), 52-59. https://doi.org/10.1111/j.1540-5885.2011.00878.x

Voegtlin, C., \& Scherer, A. G. (2017). Responsible innovation and the innovation of responsibility: Governing sustainable development in a globalized world. Journal of Business Ethics, 143(2), 227-243. https://doi.org/10.1007/s10551-015-2769-z

Voltan, A., Hervieux, C., \& Mills, A. (2017). Examining the win-win proposition of Shared Value Across Contexts: Implications for Future Application. Business Ethics. A European Review, 26(1), 347-368. https://doi.org/10.1111/beer.12159

Waddock, S. (2012). Difference making in a world of collapsing boundaries. Paper presented at the 3rd International Symposium on Cross Sector Social Interactions (May 24-25). Rotterdam: University of Erasmus.

Wheeler, D., Colbert, B., \& Freeman, R. E. (2003). Focusing on Value: Reconciling Corporate Social Responsibility, Sustainability, and a Stakeholder Approach in a Network World. Journal of General Management, 28(3), 1-28. https://doi.org/10.1177/030630700302800301

Whiteman, G., Walker, B., \& Perego, P. (2013). Planetary boundaries: Ecological foundations for corporate $\begin{array}{lllll}\text { sustainability. Journal of } & \text { Management }\end{array}$ http://dx.doi.org/10.1111/j.1467-6486.2012.01073.x 
Witt, M. A., \& Stahl, G. K. (2016). Foundations of responsible leadership: Asian versus Western executive responsibility orientations toward key stakeholders. Journal of Business Ethics, 136(3), 623-638. https://doi.org/10.1007/s10551-014-2534-8

World Economic Forum. (2016). Why social innovation matters to business. Retrieved from $\mathrm{http} / /$ reports.weforum.org/social-innovation/why-social-innovation-matters-to -business/

Wu, M. (2010). The Search for Sustainable Competitive Advantage: A Stakeholder Management Perspective (PhD Thesis). Albany: Massey University.

Zanfei, A. (2012). Playing around an oxymoron: International business with a human face. Critical Perspectives on International Business, 8(1), 56-73. https://doi.org/10.1108/17422041211197567

Zhao, M., Park, S. H., \& Zhou, N. (2014). MNC strategy and social adaptation in emerging markets. Journal of International Business Studies, 45(7), 842-861. https://doi.org/10.1057/jibs.2014.8

\section{Appendix A}

Figure-Social and Economic Value Creation through Three Levels of Shared Value Framework

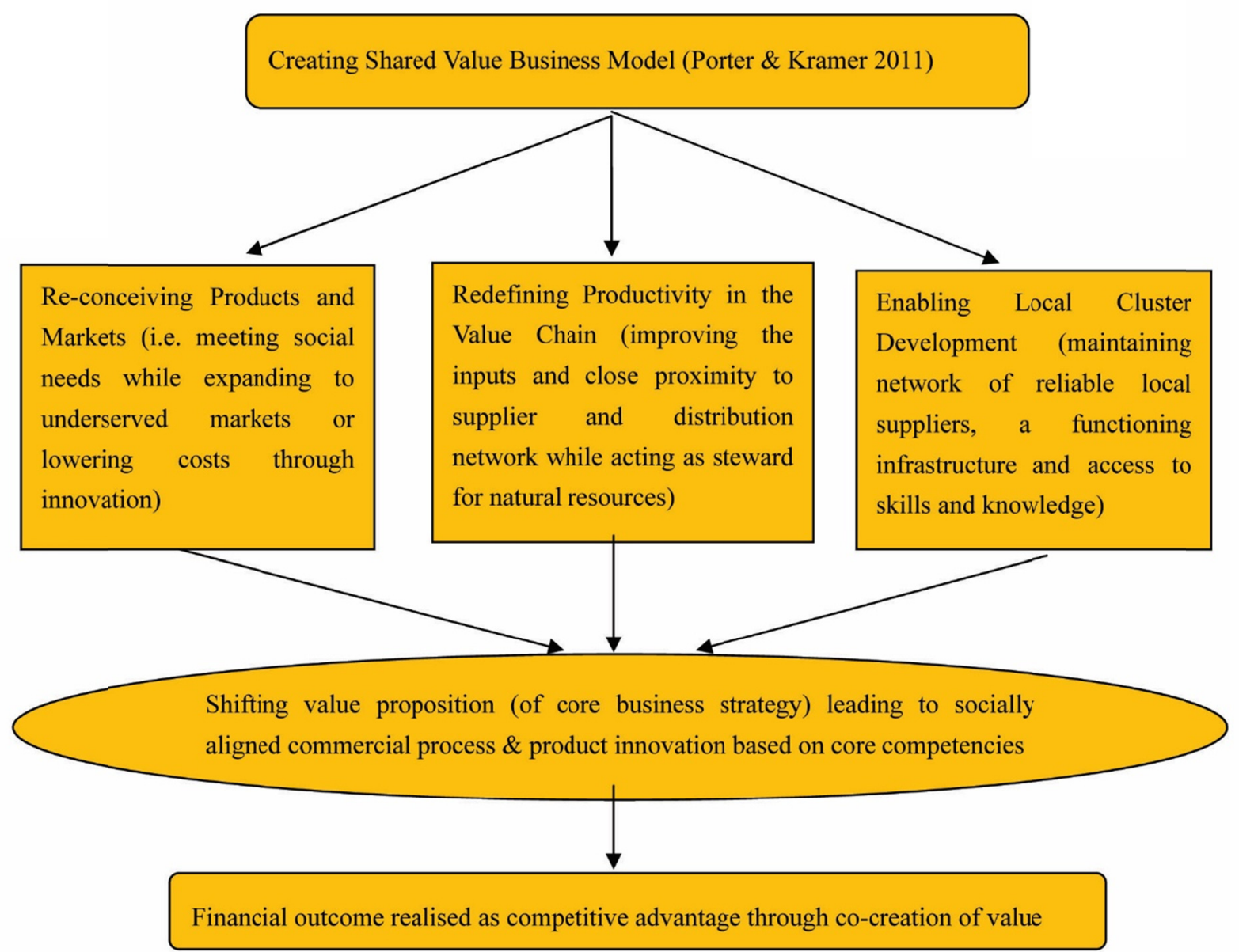

Source: Developed by the Researcher.

\section{Copyrights}

Copyright for this article is retained by the author(s), with first publication rights granted to the journal.

This is an open-access article distributed under the terms and conditions of the Creative Commons Attribution license (http://creativecommons.org/licenses/by/4.0/). 